\title{
The Splitting of Plume Centerline Height in Elevated-Source Diffusion
}

\author{
by \\ Shin'ichi Sakuraba, Minoru Moriguchi and Isao Yamazi \\ Meteorological Research Institute, Tokyo
}

(Received September 28, 1972)

\begin{abstract}
In the tracer experiment of elevated-source diffusion, sometimes there are found two peak values in the vertical concentration profile, which means two centerline-heights of concentration. One corresponds to the tracer release height and the other, the lower-level one, seems to correspond to the lower neutral or near-neutral layer. The vertical spread of concentration in the lower layer is larger than that in the upper layer. In this circumstance the surface concentration near the source is mostly determined by the diffusion from the lower-level centerline height of plume, namely the extraordinarily high surface concentration is expected to occur near the source, which cannot be explained in the light of customary knowledge of elevated-source diffusion.
\end{abstract}

\section{Introduction}

In August 1971 the field experiment of atmospheric diffusion was made at the Nyugawa area, Ehime Prefecture, Shikoku District. The Nyugawa area is located at the coastal area facing the Seto Inland Sea and the terrain is flat from the coast to about $7 \mathrm{~km}$ inland.

Fig. 1 shows the network of observation, where $S$ is the tracer release site. The vertical temperature profile was measured at four sites, $H$ 's in the figure. The vertical concentration profile was measured at three sites, $K$ 's in the figure.

The tracer release height was $100 \mathrm{~m}$ or $200 \mathrm{~m}$. When the tracer release height was $200 \mathrm{~m}$, two peak concentrations were frequently observed in the vertical concentration profile. The level of upper peak concentration is about $200 \mathrm{~m}$ and coin. cides with the tracer release height, while the level of lower peak concentration is about $100 \mathrm{~m}$. In this case the surface concentration near the source is dominated by the latter. In other words, so far as the surface concentration is concerned, this is equivalent to the change of tracer release height from $200 \mathrm{~m}$ to $100 \mathrm{~m}$, though the 


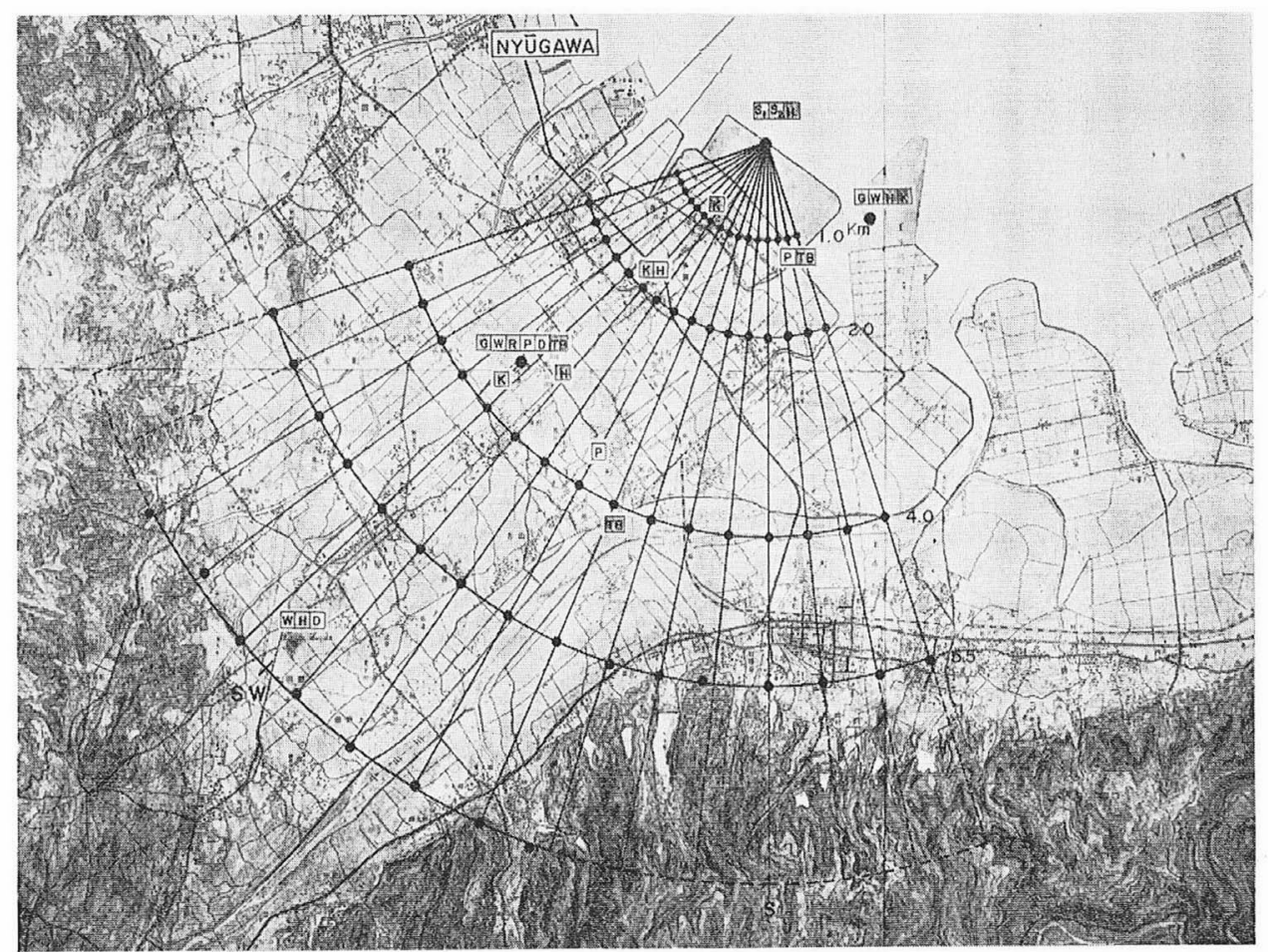

Fig. 1. Network of observation,

black circle: sampling site of surface concentration.

apparent source intensity decreases. On the other hand, when the tracer release height was $100 \mathrm{~m}$, such distribution was found to be rare.

\section{The analysis of centerline height and vertical spread of concentration}

The diffusion equation for a continuous point source is

$$
\frac{u C}{Q}=\frac{1}{2 \pi \sigma_{y} \sigma_{z}} \exp \left(-\frac{y^{2}}{2 \sigma_{y}^{2}}\right)\left[\exp \left\{-\frac{(z-\bar{z})^{2}}{2 \sigma_{z}^{2}}\right\}+\exp \left\{-\frac{(z+\bar{z})^{2}}{2 \sigma_{z}^{2}}\right\}\right]
$$

Here $\bar{z}$ is the centerline height of concentration. $\bar{z}$ is usually interpreted as the effective height of emission or the tracer release height and assumed constant independent of downwind distance. However, the centerline height of concentration is, in general, not constant, as reported in our previous paper (SAKURABA and others, 1972). The other notations are customary ones.

The vertical distribution of concentration is, from Eq. (1),

$$
\begin{gathered}
C(x, y, z) / C_{0}=\left[\exp \left\{-\frac{(\eta-1)^{2}}{2 \xi^{2}}\right\}+\exp \left\{-\frac{(\eta+1)^{2}}{2 \xi^{2}}\right\}\right] / 2 \exp \left(-\frac{1}{2 \xi^{2}}\right) \\
\quad C_{0}=C(x, y, 0) \\
\xi=\sigma_{z} / \bar{z} \quad \quad \eta=z / \bar{z}
\end{gathered}
$$

When the surface concentration $C_{0}$ is zero or very small, the second term in brackets of Eq. (1), which shows the reflected part of concentration from the surface, is 
negligible and the vertical distribution of concentration becomes

$$
C \infty \exp \left\{-\frac{(z-\bar{z})^{2}}{2 \sigma_{z}^{2}}\right\}
$$

From the measurement of vertical distribution of concentration downwind of the source, both the centerline height of concentration $\bar{z}$ and the vertical spread of concentration $\sigma_{z}$ can be determined, by Eq. (2) or (3).

\section{Experiment 1,10:00-10:30 8th August 1971}

The tracer was released at $200 \mathrm{~m}$ level and the release period was 30 minutes from 10:00 to 10:30. The pilot ballon observation was made near the tracer release site and the result is shown in Figs. 2 and 3.

The vertical distribution of temperature was measured at four sites: $H_{1}, H_{2}, H_{3}$ and $H_{4}$. Their distances from the tracer release site are as follows:

$H_{1}$ : shoreline near the tracer release site

$$
H_{2}: \quad 1.8 \mathrm{~km} \quad H_{3}: \quad 3.5 \mathrm{~km} \quad H_{4}: \quad 7.0 \mathrm{~km}
$$

The vertical temperature profiles at 11:15-11:33 are shown in Fig. 4. Here the dotted line is the dry adiabat. At $H_{1}, H_{2}$ and $H_{3}$ it is drawn through $28^{\circ} \mathrm{C}$ at the surface, while at $H_{4}$ through $29^{\circ} \mathrm{C}$.

In these temperature profiles the stable lapse layer aloft is first to be noticed, which seems to have much affected the concentration profile to be stated subsequently. At $H_{1}$, it is between $250 \mathrm{~m}$ and $350 \mathrm{~m}$ and the lapse rate is $0.2^{\circ} \mathrm{C} / 100 \mathrm{~m}$, while at $H_{3}$ it is between $150 \mathrm{~m}$ and $250 \mathrm{~m}$, the lapse rate being $0.3^{\circ} \mathrm{C} / 100 \mathrm{~m}$. At $H_{2}$ the cor-

Aug. 8. 1971. (NYUGAWA)

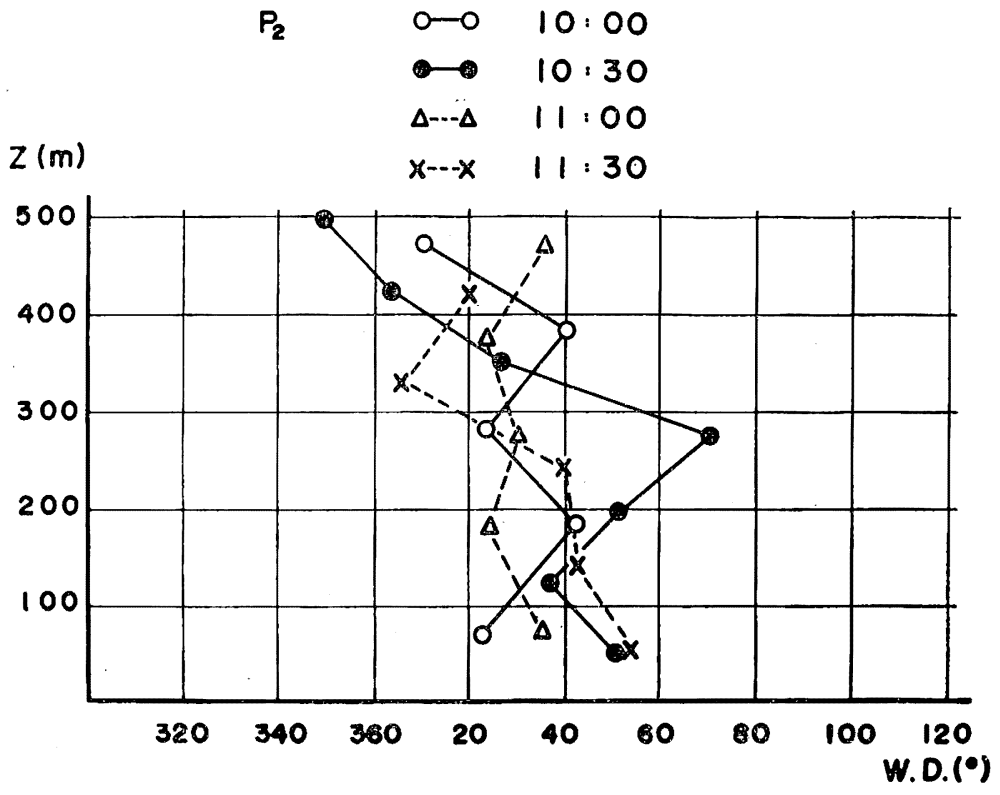

Fig. 2. Wind-direction profiles. 
Aug. 8. 1971. (NYUGAWA)

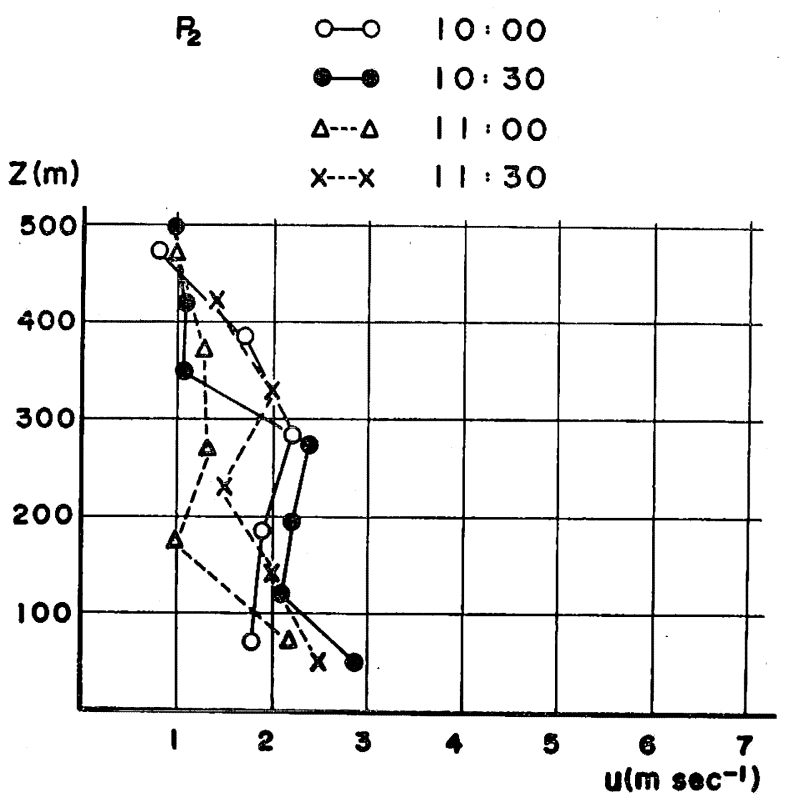

Fig. 3. Wind-speed profiles.

Aug. 8. 1971 . (NYUGAWA)

$11: 15-11: 33$

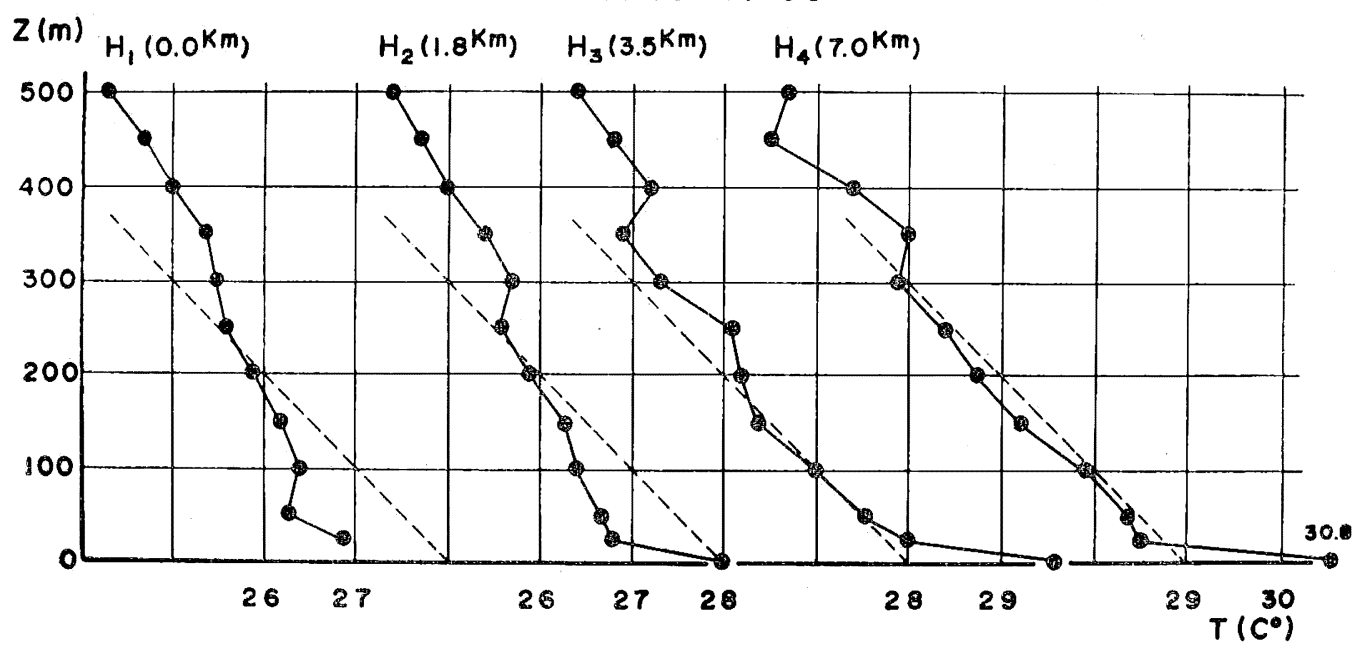

Fig. 4. Vertical temperature profiles at four sites. 


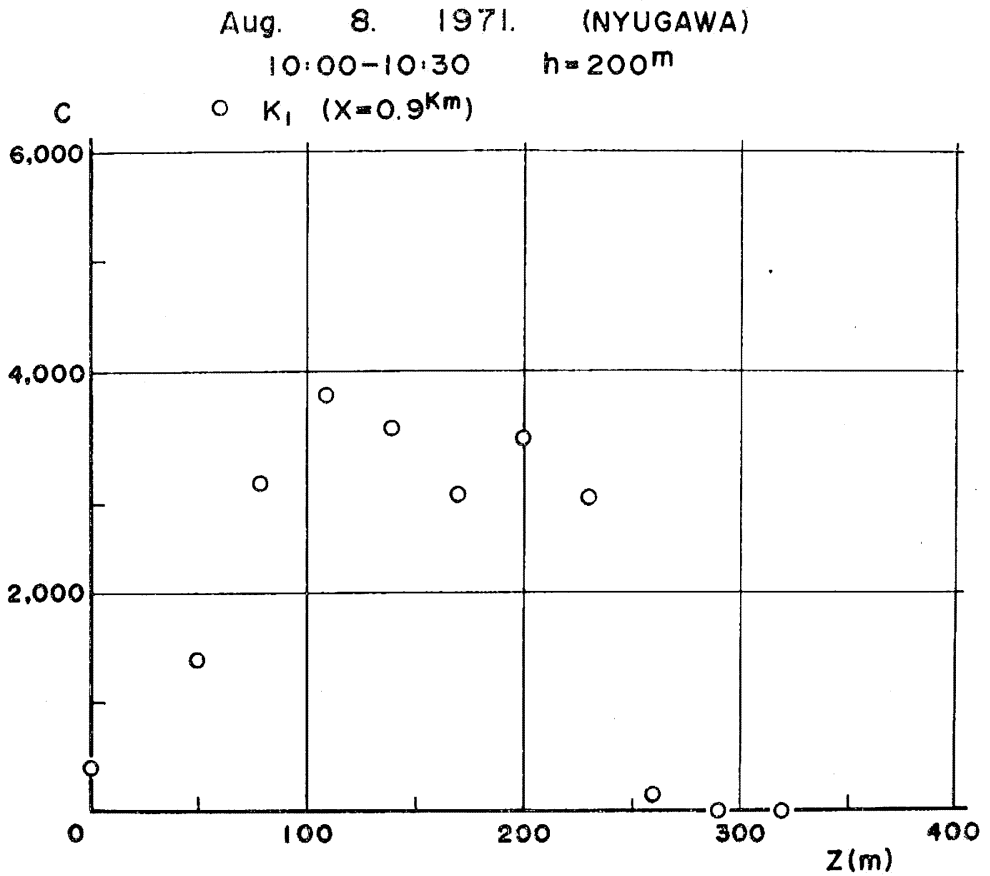

Fig. 5. Vertical concentration profile at $K_{1}$.

Ordinate: concentration in relative unit.

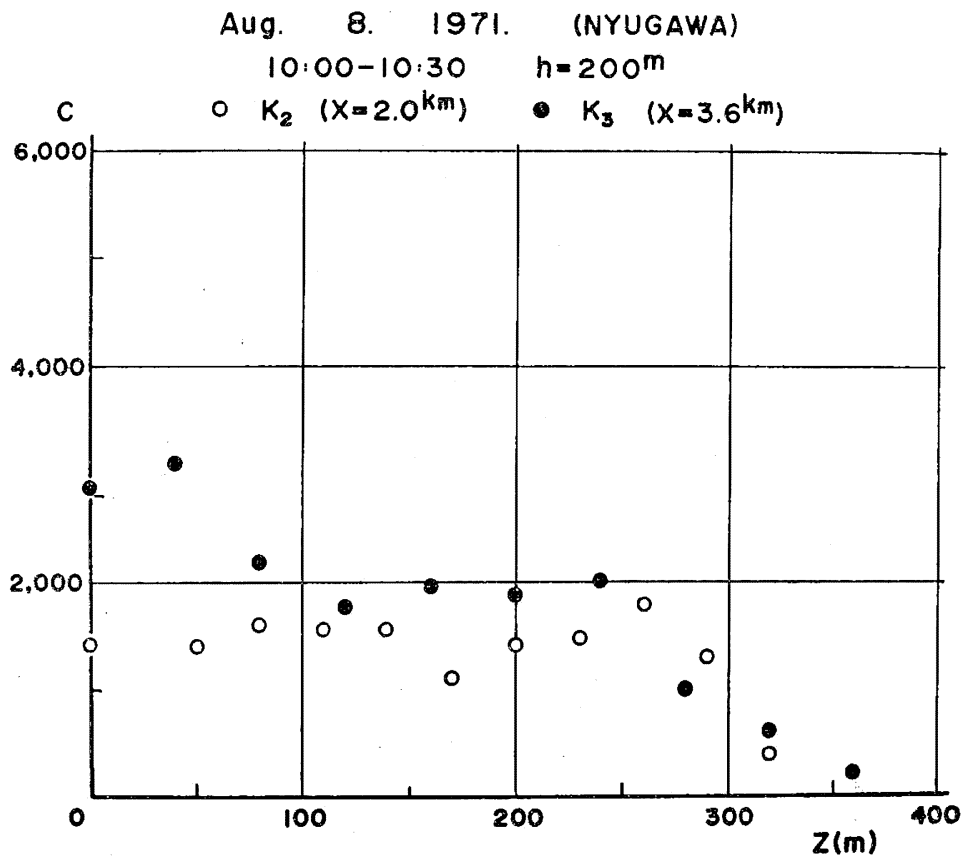

Fig. 6. Vertical concentration profiles at $K_{2}$ and $K_{3}$. 
responding layer seems to lie between $200 \mathrm{~m}$ and $300 \mathrm{~m}$.

The inland modification of sea breeze due to the heating from the surface is not yet conspicuous at $\mathrm{H}_{2}$, but the potential temperature is the same at the surface and about $200 \mathrm{~m}$ level, so the neutral layer is expected to grow rapidly downwind of $H_{2}$. In fact, at $H_{3}$, the temperature profile below $150 \mathrm{~m}$ level coincides with the dry adiabat through $28^{\circ} \mathrm{C}$ at the surface, except for the shallow layer close to the ground. At $H_{4}$ the neutral layer extends up to $300 \mathrm{~m}$ level.

The vertical distribution of concentration was measured at three sites: $K_{1}, K_{2}$ and $K_{3}$. Their distances from the tracer release site are as follows:

$$
K_{1}: \quad 0.9 \mathrm{~km} \quad K_{2}: \quad 2.0 \mathrm{~km} \quad K_{3}: \quad 3.6 \mathrm{~km}
$$

$K_{2}$ and $H_{2}$ are about the same in distance from the source. The same is the case with $K_{3}$ and $H_{3}$.

The vertical concentration profile measured at $K_{1}$ is shown in Fig. 5 and those at $K_{2}$ and $K_{3}$ are in Fig. 6. Fig. 5 shows two peak concentrations, one at about $110 \mathrm{~m}$ level and the other at $200 \mathrm{~m}$ level. In Fig. 6 the lower part of concentration is much affected by the reflected concentration from the surface. However it is evident that each profile has two peak concentrations.

When the vertical distribution of concentration is represented by one pair of $\left(\bar{z}, \sigma_{z}\right)$, there occurs only one peak value in the vertical distribution, as is evident from Eq. (2) or (3). So, to express the concentration profile as in Fig. 5 or 6, two pairs of $\left(\bar{z}, \sigma_{z}\right)$ are needed.

Assuming that the concentration profile in Fig. 5 is expressible by the sum of two different Gaussian curves, the lower part of the concentration profile is analyzed in Fig. 7 and the upper part in Fig. 8. In both figures the ordinate is the ratio of concentration at any altitude $z$ to that at $\bar{z}$ and the abscissa is $(z-\bar{z}) / \sigma_{\tilde{z}}$. The full curve is the Gaussian curve.

$$
\begin{array}{ll}
\bar{z}_{1}=120 \mathrm{~m} & \sigma_{z 1}=55 \mathrm{~m}(C) \\
\bar{z}_{2}=200 \mathrm{~m} & \sigma_{z 2}=27 \mathrm{~m}(D)
\end{array}
$$

Here $\bar{z}_{1}$ and $\sigma_{z 1}$ are the centerline height and the vertical spread of concentration respectively representing the lower part of the concentration profile, while $\bar{z}_{2}$ and $\sigma_{\approx 2}$ are those of the upper part.

Plotting $\sigma_{z 1}=55 \mathrm{~m}$ at $x=0.9 \mathrm{~km}$ on Pasquill's $\sigma_{z}-x$ chart (TURNER, 1967), the Pasquill stability of $\sigma_{z 1}$ is found to be $C$, where $x$ is the downind distance. In like manner the Pasquill stability of $\sigma_{z 2}$ is D. This shows that the vertical diffusion rate around $100 \mathrm{~m}$ level is larger than that of $200 \mathrm{~m}$ level.

$200 \mathrm{~m}$ coincides with the tracer release height and its meaning is self-evident. The mechanism of formation of another lower centerline height $\bar{z}_{1}=120 \mathrm{~m}$ is not necessarily evident at this stage. It is important to notice here that, as is evident from the visual inspection of Fig. 5, the concentration with the centerline height at $200 \mathrm{~m}$ has no effect on the surface concentration. The surface concentration is entirely determined by the concentration with the centerline height at $120 \mathrm{~m}$. This means that, so far as the surface concentration is concerned, the centerline height of concentration is not $200 \mathrm{~m}$ but $120 \mathrm{~m}$. Furthermore the Pasquill stability of $\sigma_{z}$ is not $D$ but $C$.

The lower part of concentration profile at $K_{2}$ is analyzed in Fig. 9 and the upper 


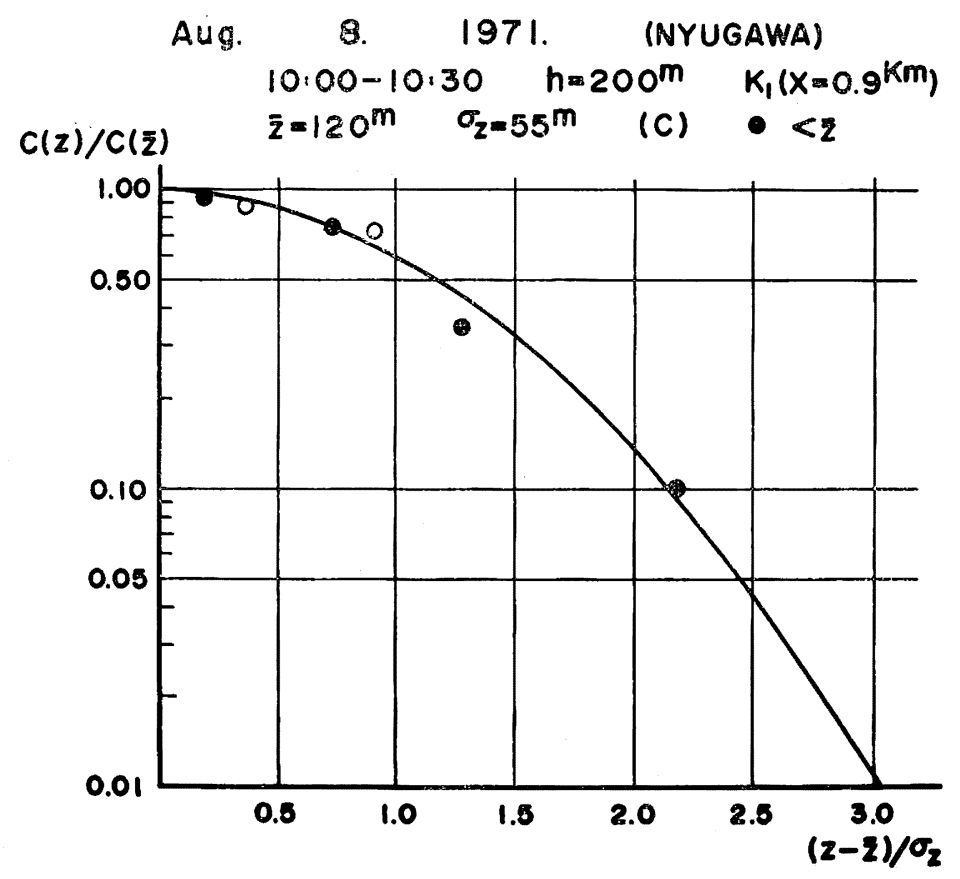

Fig. 7. Analysis of the lower part of concentration at $K_{1}$.

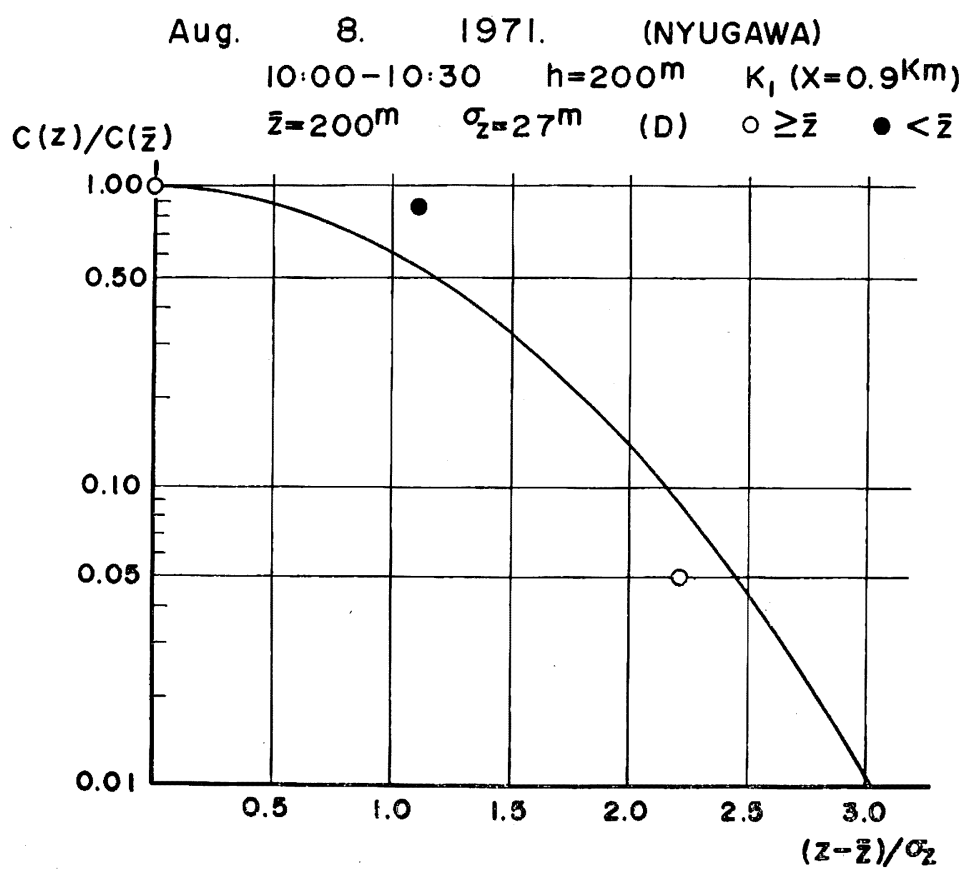

Fig. 8. Anaysis of the upper part of concentration at $K_{1}$. 


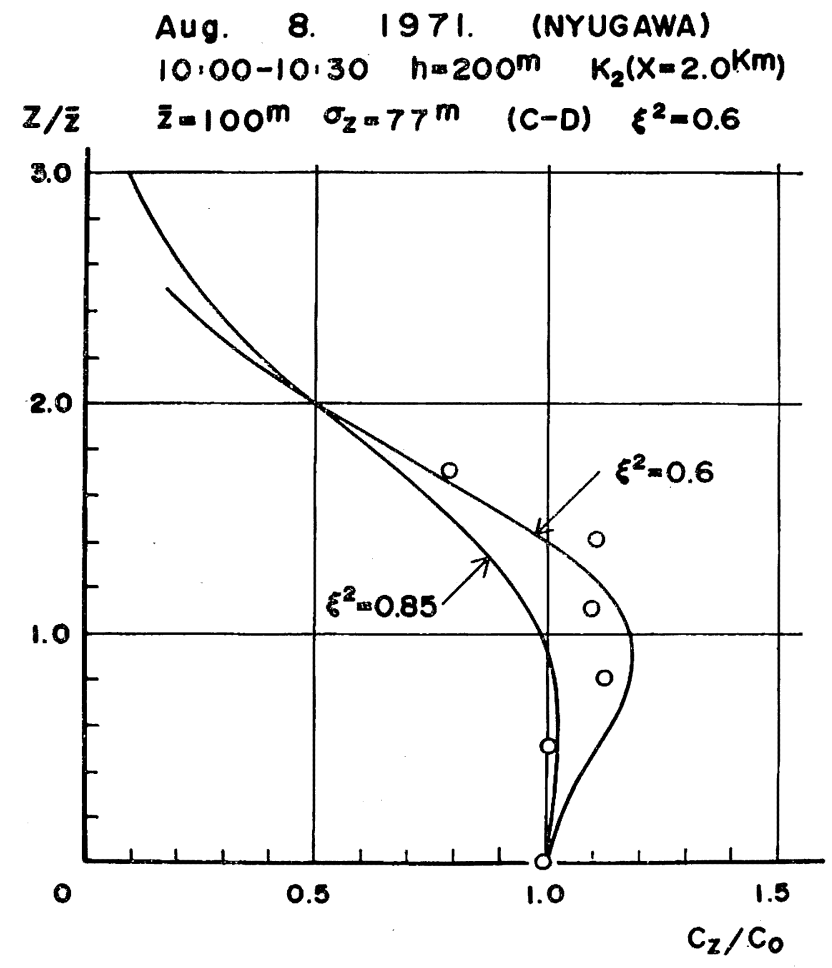

Fig. 9. Same as Fig. 7 but for $K_{2}$.

part in Fig. 10. In Fig. 9 the ordinate is $z / \bar{z}$ and the abscissa is $C / C_{0}, C_{0}$ being the surface concentration. The parameter $\xi$ is $\sigma_{z} / \bar{z}$.

$$
\begin{array}{lll}
\bar{z}=100 \mathrm{~m} & \xi^{2}=0.6 & \sigma_{z 1}=77 \mathrm{~m}(C-D) \\
\bar{z}=240 \mathrm{~m} & & \sigma_{z 2}=45 \mathrm{~m}(D)
\end{array}
$$

Here $C-D$ means that the Pasquill stability is near the midpoint between $C$ and $D$.

$\bar{z}=240 \mathrm{~m}$ corresponds to the tracer release height, though the height difference between the two is $40 \mathrm{~m}$. Such minor rise or descent of plume centerline is not rare even over a flat terrain. It is to be noticed that $\bar{z}_{2}$ lies in the stable $200 \mathrm{~m}-300 \mathrm{~m}$ layer observed at $\mathrm{H}_{2}$

$\bar{z}_{1}=100 \mathrm{~m}$ is the lower-level centerline height and the Pasquill stability of $\sigma_{z}$ below about $100 \mathrm{~m}$ level is $C-D$, which suggests that the layer from the surface to about $100 \mathrm{~m}$ level is neutral or near-neutral. It is well known from the diffusion experiment that the Pasquill stability of $\sigma_{\mathrm{z}}$ is on the average $C-D$ in the neutral layer when the downwind distance exceeds $1 \mathrm{~km}$. As already remarked, the neutral layer is expected to grow rapidly downwind of $H_{2}$, so it is probable that the diffusion below $100 \mathrm{~m}$ level has become that of near-neutral layer at $K_{2}$.

The lower part of concentration at $K_{3}$ is analyzed in Fig. 11 and the upper part in Fig. 12. 


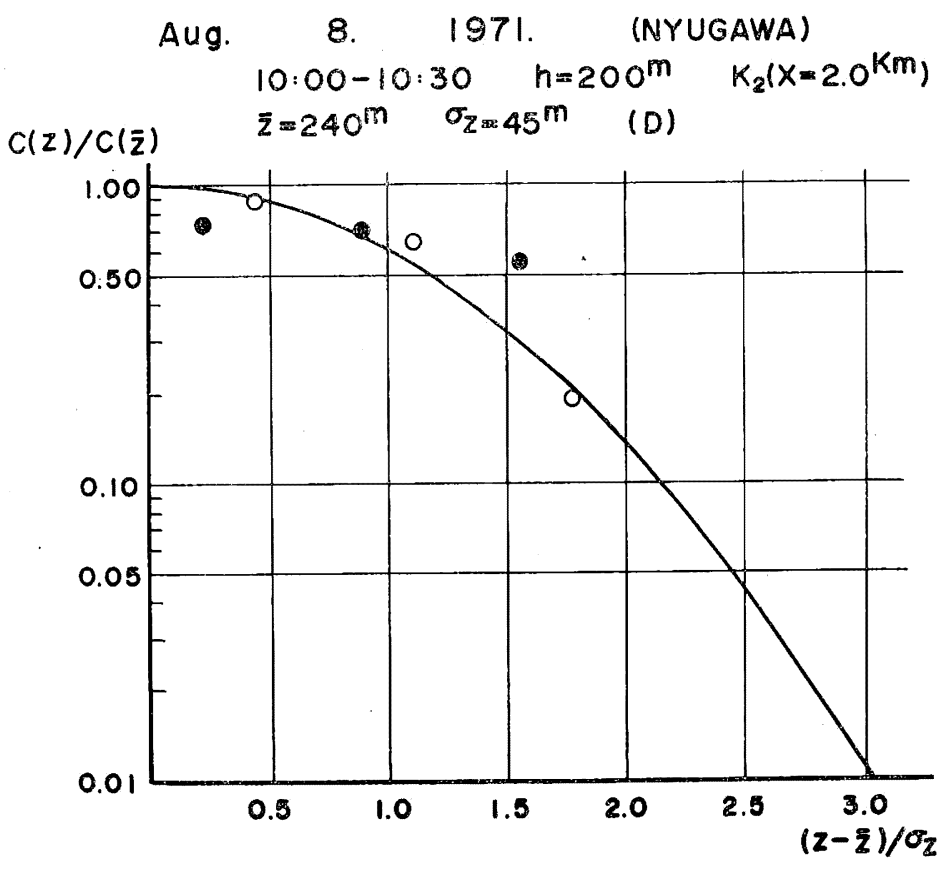

Fig. 10. Same as Fig. 8 but for $K_{2}$.

$$
\begin{array}{lll}
\bar{z}_{1}=90 \mathrm{~m} & \xi^{2}=0.85 & \sigma_{z 1}=83 \mathrm{~m}(C-D) \\
\bar{z}_{2}=220 \mathrm{~m} & & \sigma_{z 2}=60 \mathrm{~m}(D-E)
\end{array}
$$

$\bar{z}_{1}=90 \mathrm{~m}$ is located in the neutral layer extending to $150 \mathrm{~m}$ level, as shown in the temperature profile at $H_{3}$, though the coincidence between observation and calculation is not good in Fig. 11. The Pasquill stability $C-D$ of $\sigma_{z 1}$ is acceptable as the vertical diffusion rate in the neutral layer. $\bar{z}_{2}=220 \mathrm{~m}$ is in the stable $150 \mathrm{~m}-250 \mathrm{~m}$ layer and corresponds to the tracer release height. The Pasquill stability $D-E$ of $\sigma_{* 2}$ is reasonable as the vertical diffusion rate in the stable lapse layer.

The splitting of centerline height of concentration into two seems to have some connection with the thermal stratification of the layer concerned, namely the stable layer aloft and the underlying relatively unstable layer, though the role of winddirection shear shown in Fig. 2 cannot be ignored. In case of $K_{2}$ and $K_{3}$, the neutral or near-neutral layer extends up to $100 \mathrm{~m}$ or $150 \mathrm{~m}$ level, above which lies the stable lapse layer.

\section{Experiment 2, $10: 40-11: 10$ 8th August 1971}

40 minutes later the second experiment of this day was made. This time the tracer release height was $100 \mathrm{~m}$.

The vertical distribution of concentration at $K_{1}$ is shown in Fig. 13 and those at $K_{2}$ and $K_{3}$ in Fig. 14. Except $K_{1}$, each profile has one peak value of concentration, normal profile, which is quite different from the case of Experiment 1. 
Aug. 8. 1971 . (NYUGAWA) $10: 00-10: 30 \quad h=200 \mathrm{~m} \quad K_{3}(X=3.6 \mathrm{Km})$ $Z / \bar{z} \quad \bar{z}=90^{\mathrm{m}} \quad \sigma_{z}=83 \mathrm{~m} \quad(C-D) \quad \xi^{2}=0.85$

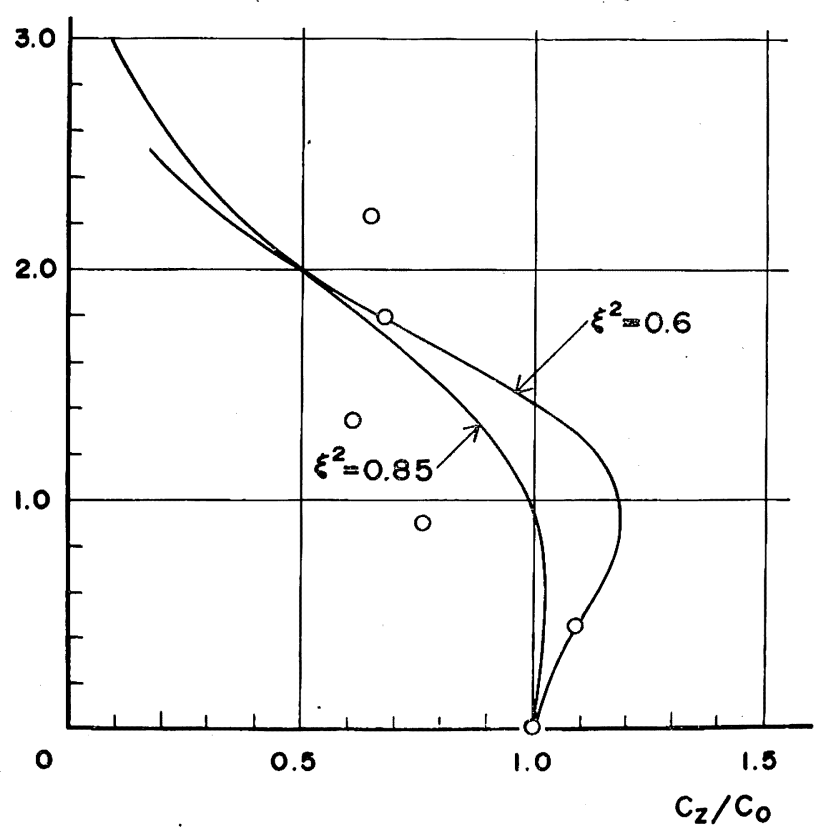

Fig. 11. Same as Fig. 7 but for $K_{3}$.

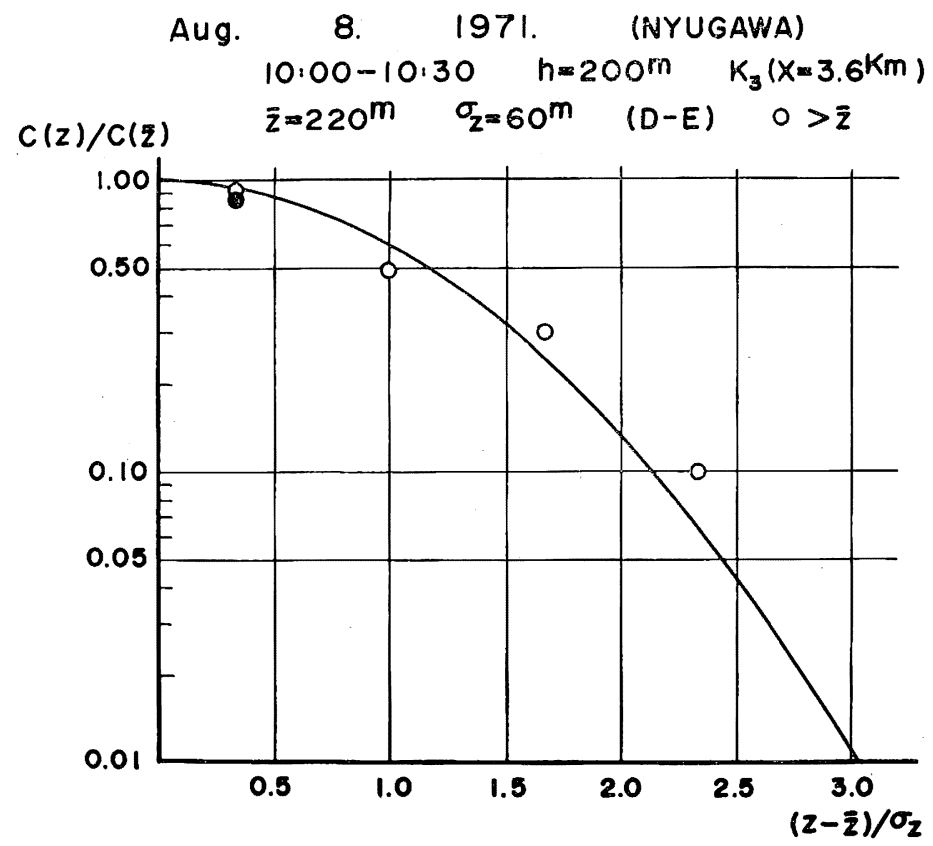

Fig. 12. Same as Fig. 8 but for $K_{3}$. 


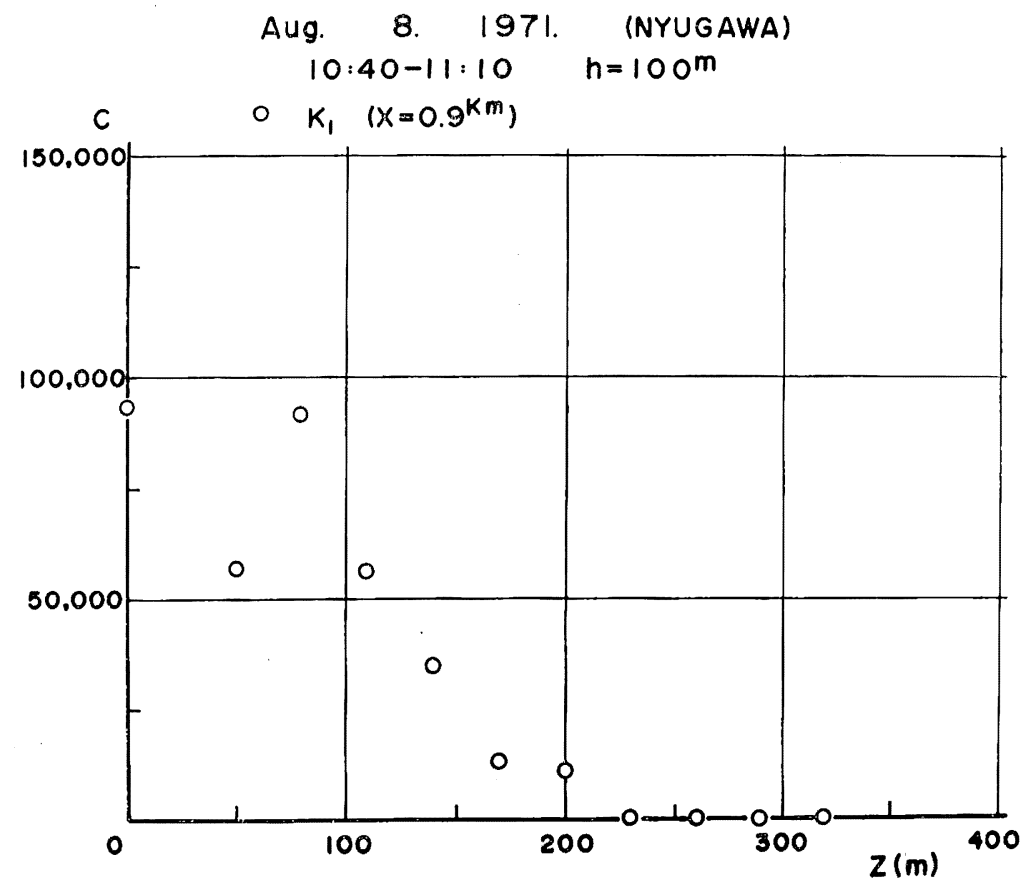

Fig. 13. Vertical concentration profile at $K_{1}$.

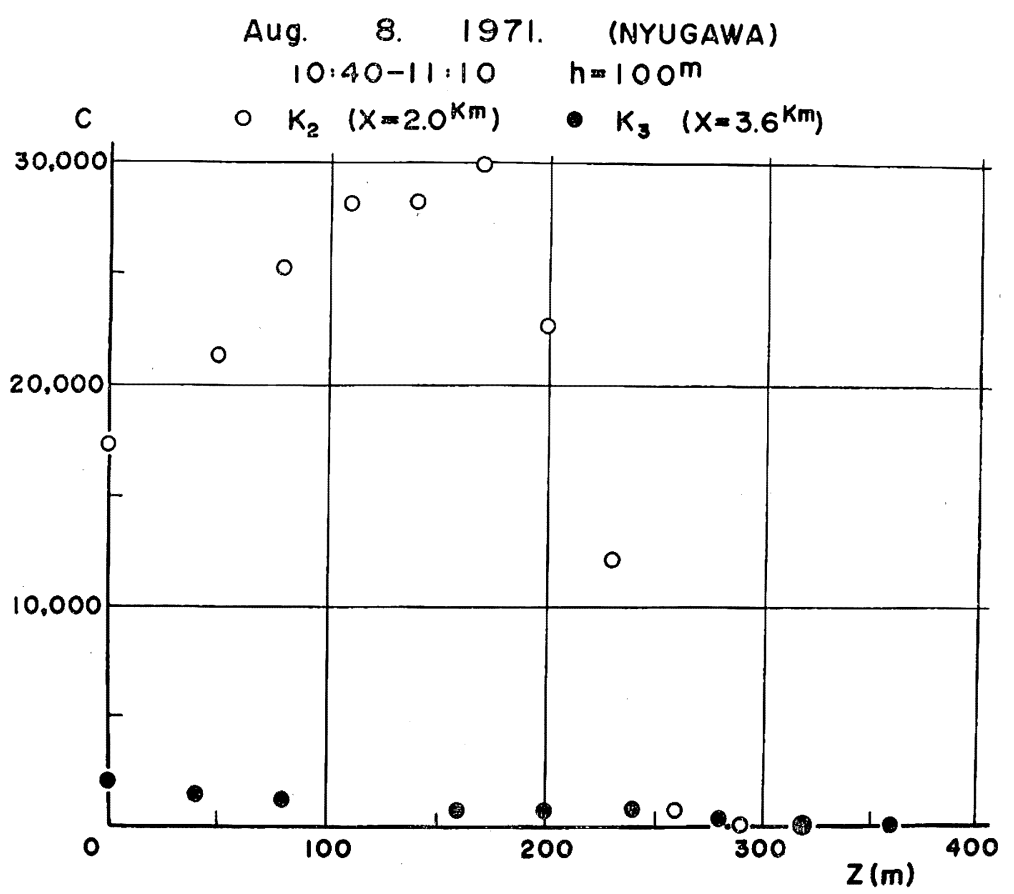

Fig. 14. Vertical concentration profiles at $K_{2}$ and $K_{3}$. 


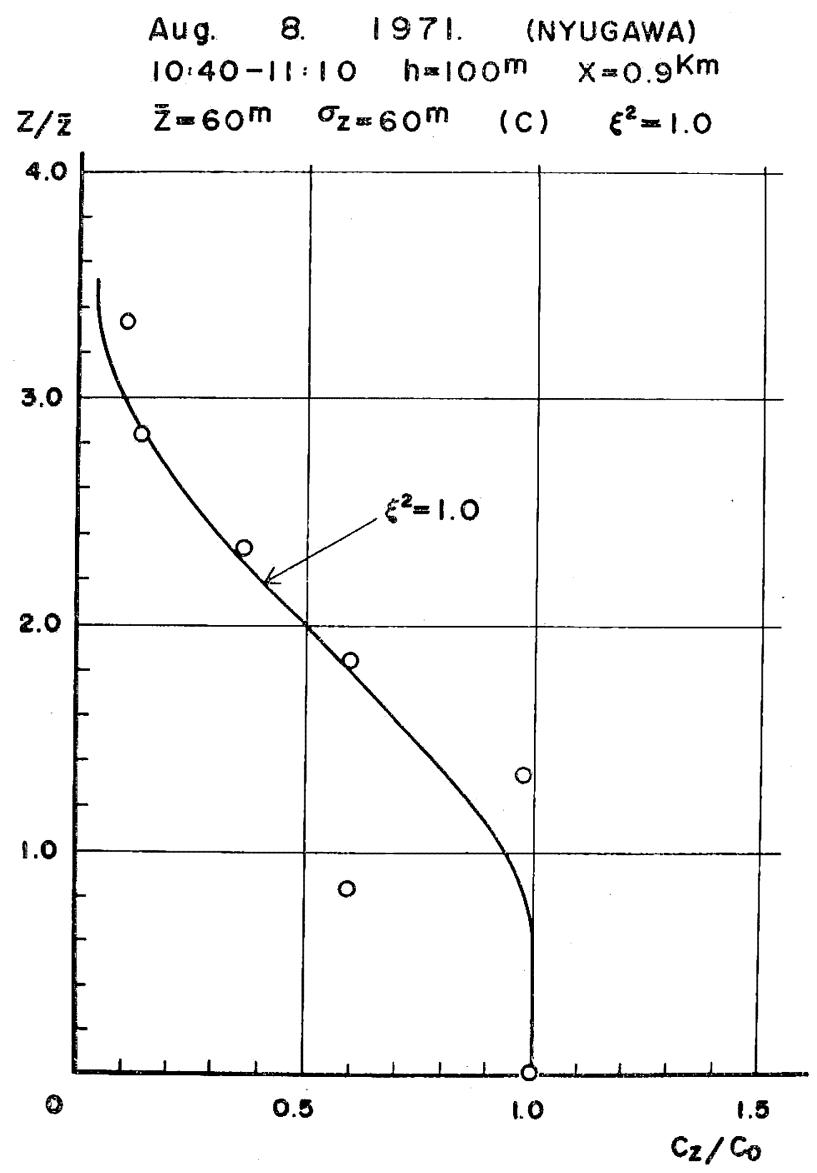

Fig. 15. Analysis of the concentration profile at $K_{1}$.

Though the profile at $K_{1}$ has two peak values of concentration, it is difficult to analyze the lower part of concentration. So, assuming that the concentration profile consists of a single Gaussian curve, the analysis is shown in Fig. 15.

$$
\bar{z}=60 \mathrm{~m} \quad \xi^{2}=1 \quad \sigma_{z}=60 \mathrm{~m}(C)
$$

The Pasquill stability of $\sigma_{z}$ is $C$ and equal to that of the lower part of concentration at $K_{1}$ in Experiment $1 . \bar{z}=60 \mathrm{~m}$ corresponds to the tracer release height.

The concentration profile at $K_{2}$ is analyzed in Fig. 16.

$$
\bar{z}=130 \mathrm{~m} \quad \xi^{2}=0.4 \quad \sigma_{z}=82 \mathrm{~m}(C-D)
$$

Similarly the Pasquill stability of $\sigma_{z}$ is the same as that of the lower part of concentration at $K_{2}$ in Experiment 1 . The concentration at $K_{3}$ is very low and correspondingly the accuracy of analysis is not good compared with that of $K_{1}$ or $K_{2}$, which is reflected in Fig. 17.

$$
\bar{z}=70 \mathrm{~m} \quad \xi^{2}=3 \quad \sigma_{z}=121 \mathrm{~m}(C-D)
$$

It must be emphasized here that, when the tracer release height is $100 \mathrm{~m}$, the 


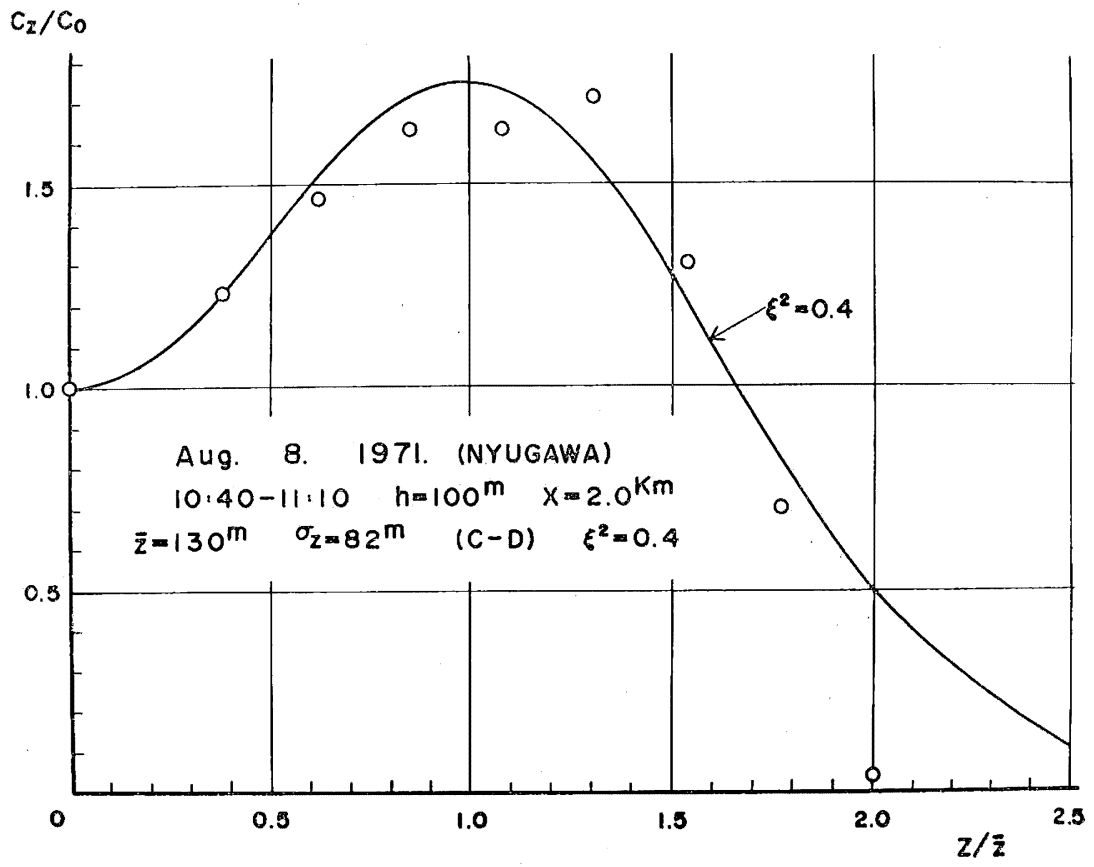

Fig. 16. Same as Fig. 15 but for $K_{2}$.

splitting of centerline height of concentration does not occur, in contrast with a conspicuous splitting when the tracer release height is $200 \mathrm{~m}$. The atmospheric layer is considered almost the same in both cases.

\section{The concentration in case of two centerline heights of concentration}

Normally there is only one centerline height of concentration, $\bar{z}$ in the present notation, corresponding to the tracer release height or the effective height of emission. However, in some conditions, there occur two centerline heights, one corresponding to the tracer release height in the stable layer and the other to the underlying relatively unstable layer, as stated in Section 3. In this case the low-level centerline dominates the surface concentration near the source.

Let the centerline height of concentration in the upper layer be $\bar{z}_{2}$ and that in the lower layer be $\vec{z}_{1}$, then the diffusion equation is

$$
\begin{aligned}
& \frac{2 \pi \sigma_{y}}{\exp \left(-y^{2} / 2 \sigma_{y}{ }^{2}\right)} \frac{u C}{Q}=\frac{\alpha_{1}}{\sigma_{z 1}}\left[\exp \left\{-\frac{\left(z-\bar{z}_{1}\right)^{2}}{2 \sigma_{z 1}{ }^{2}}\right\}+\exp \left\{-\frac{\left(z+\bar{z}_{1}\right)^{2}}{2 \sigma_{z 1}{ }^{2}}\right\}\right] \\
&+\frac{\alpha_{2}}{\sigma_{z 2}}\left[\exp \left\{-\frac{\left(z-\bar{z}_{2}\right)^{2}}{2 \sigma_{z 2}{ }^{2}}\right\}+\exp \left\{-\frac{\left(z+\bar{z}_{2}\right)^{2}}{2 \sigma_{z 2}{ }^{2}}\right\}\right] \\
& \alpha_{1}+\alpha_{2}=1
\end{aligned}
$$

Eq. (5) comes from the continuity condition

$$
\int_{0}^{\infty} \int_{-\infty}^{\infty} \frac{u C}{Q} d y d z=1
$$




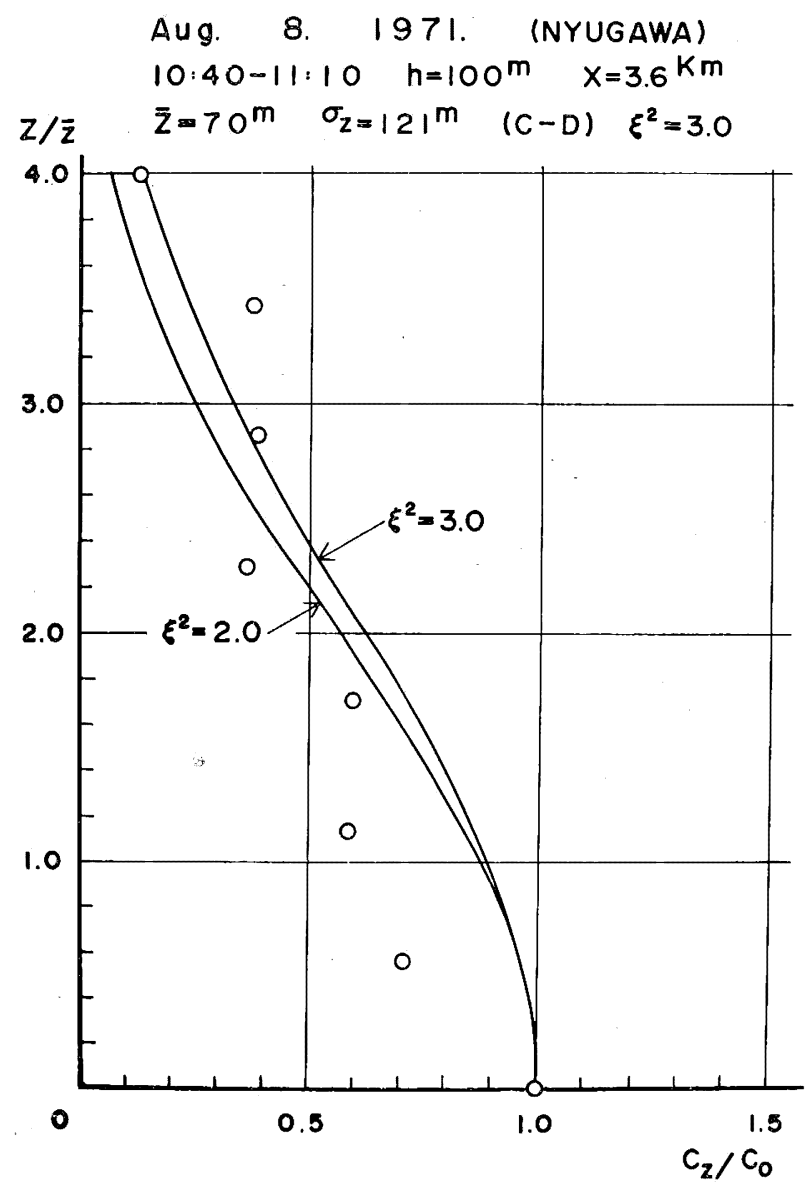

Fig. 17. Same as Fig. 15 but for $K_{3}$.

$\sigma_{z 1}$ and $\sigma_{z 2}$ correspond to $\bar{z}_{1}$ and $\bar{z}_{2}$ respectively, and the horizontal spread of concentration $\sigma_{y}$ is assumed to be common to $\bar{z}_{1}$ and $\bar{z}_{2}$. The surface axial concentration $C_{a}$ is

$$
\frac{u C_{a}}{Q}=\frac{1}{\pi \sigma_{y}}\left[\frac{\alpha_{1}}{\sigma_{z 1}} \exp \left(-\frac{\bar{z}_{1}{ }^{2}}{2 \sigma_{z 1}{ }^{2}}\right)+\frac{\alpha_{2}}{\sigma_{z 2}} \exp \left(-\frac{\bar{z}_{2}^{2}}{2 \sigma_{z 2}{ }^{2}}\right)\right]
$$

or

$$
\begin{gathered}
\frac{u C_{a 1}}{\alpha_{1} Q}=\frac{1}{\pi \sigma_{y} \sigma_{z 1}} \exp \left(-\bar{z}_{1}^{2} / 2 \sigma_{z 1}{ }^{2}\right) \\
\frac{u C_{a 2}}{\alpha_{2} Q}=\frac{1}{\pi \sigma_{y} \sigma_{z 2}} \exp \left(-\bar{z}_{2}^{2} / 2 \sigma_{z 2}{ }^{2}\right) \\
C_{a}=C_{a 1}+C_{a 2}
\end{gathered}
$$

To assess quantitatively the surface concentration given by Eq. (8) or (9), the following values corresponding to the analysis in Section 3 will be adopted: 


$$
\begin{array}{ll}
\bar{z}_{1}=100 \mathrm{~m} & \bar{z}_{2}=200 \mathrm{~m} \\
\sigma_{z 1}(C-D) & \sigma_{z 2}(D)
\end{array}
$$

Here $\sigma_{z 1}(C-D)$ means that the Pasquill stability of $\sigma_{z 1}$ is $C-D$, and so on. The magnitude of $\sigma_{z}$ varies with the downwind distance $x$ as follows:

\begin{tabular}{l|ccccc}
\hline \hline \multicolumn{1}{c|}{$x$} & 1 & 2 & 3 & 4 & $\mathrm{~km}$ \\
\hline$\sigma_{z 1}(C-D)$ & 44 & 76 & 104 & 130 & $\mathrm{~m}$ \\
$\sigma_{z 2}(D)$ & 32 & 50 & 64 & 77 & $\mathrm{~m}$ \\
$\sigma_{z 2} / \sigma_{z 1}$ & 0.73 & 0.66 & 0.62 & 0.59 & \\
\hline
\end{tabular}

To determine $\alpha_{1}$ and $\alpha_{2}$, let $C\left(\bar{z}_{1}\right)$ be the concentration at $\bar{z}_{1}$ and $C\left(\bar{z}_{2}\right)$ that at $\bar{z}_{2}$, then

$$
\begin{aligned}
& \frac{C\left(\bar{z}_{1}\right)}{C\left(\bar{z}_{2}\right)} \\
= & \frac{\frac{\alpha_{1}}{\sigma_{z 1}}\left[1+\exp \left(-\frac{4 \bar{z}_{1}{ }^{2}}{2 \sigma_{z 1}{ }^{2}}\right)\right]+\frac{\alpha_{2}}{\sigma_{z 2}}\left[\exp \left\{-\frac{\left(\bar{z}_{1}-\bar{z}_{2}\right)^{2}}{2 \sigma_{z 2}{ }^{2}}\right\}+\exp \left\{-\frac{\left(\bar{z}_{1}+\bar{z}_{2}\right)^{2}}{2 \sigma_{z 2}{ }^{2}}\right\}\right]}{\frac{\alpha_{1}}{\sigma_{z 1}}\left[\exp \left\{-\frac{\left(\bar{z}_{2}-\bar{z}_{1}\right)^{2}}{2 \sigma_{z 1}{ }^{2}}\right\}+\exp \left\{-\frac{\left(\bar{z}_{2}+\bar{z}_{1}\right)^{2}}{2 \sigma_{z 1}{ }^{2}}\right\}\right]+\frac{\alpha_{2}}{\sigma_{z 2}}\left[1+\exp \left(-\frac{4 \bar{z}_{2}{ }^{2}}{2 \sigma_{z 2}{ }^{2}}\right)\right]}
\end{aligned}
$$

At $x=1 \mathrm{~km}$ or so where the magnitude of $\sigma_{z}$ is rather small, Eq. (11) is approximately

$$
\frac{C\left(\bar{z}_{1}\right)}{C\left(\bar{z}_{2}\right)} \approx \frac{\alpha_{1}}{\alpha_{2}} \frac{\sigma_{z 2}}{\sigma_{z 1}}
$$

In case of $C\left(\bar{z}_{1}\right) \approx C\left(\bar{z}_{2}\right)$, as is the case in Fig. 5 ,

$$
\alpha_{1}=0.58 \quad \alpha_{2}=0.42
$$

by $\sigma_{z 2} / \sigma_{* 1}=0.73$ and the condition (5).

The righthand side of Eq. (8) is calculated in Fig. 18 and that of Eq. (9) in Fig. 19. Exactly speaking, $\sigma_{\nu}$ of Fig. 18 is different from that of Fig. 19, which, however, has no practical effect on the subsequent discussion.

From Fig. 18 and 19

\begin{tabular}{c|ccccc}
\hline$x$ & 1 & 2 & 3 & 4 & $\mathrm{~km}$ \\
\hline$\frac{u C_{a 1}}{\alpha_{1} Q}$ & 6.6 & 11.0 & 8.2 & 6.0 & $\times 10^{-6} \mathrm{~m}^{-2}$ \\
$\frac{u C_{a 1}}{Q}$ & 3.8 & 6.4 & 4.8 & 3.5 & $\prime \prime$ \\
$\frac{u C_{a 2}}{\alpha_{2} Q}$ & 0 & 0 & 0.2 & 0.6 & $\prime \prime$ \\
$\frac{u C_{a 2}}{Q}$ & 0 & 0 & 0.1 & 0.3 & $\prime \prime$ \\
\hline
\end{tabular}

Evidently the surface concentration is determined by the low-level centerline height and the high-level centerline height has practically no effect down to $4 \mathrm{~km}$ or so. This means the lowering of centerline height from $200 \mathrm{~m}$ to $100 \mathrm{~m}$, so far as the surface concentration is concerned, though the source intensity is apparently reduced. 


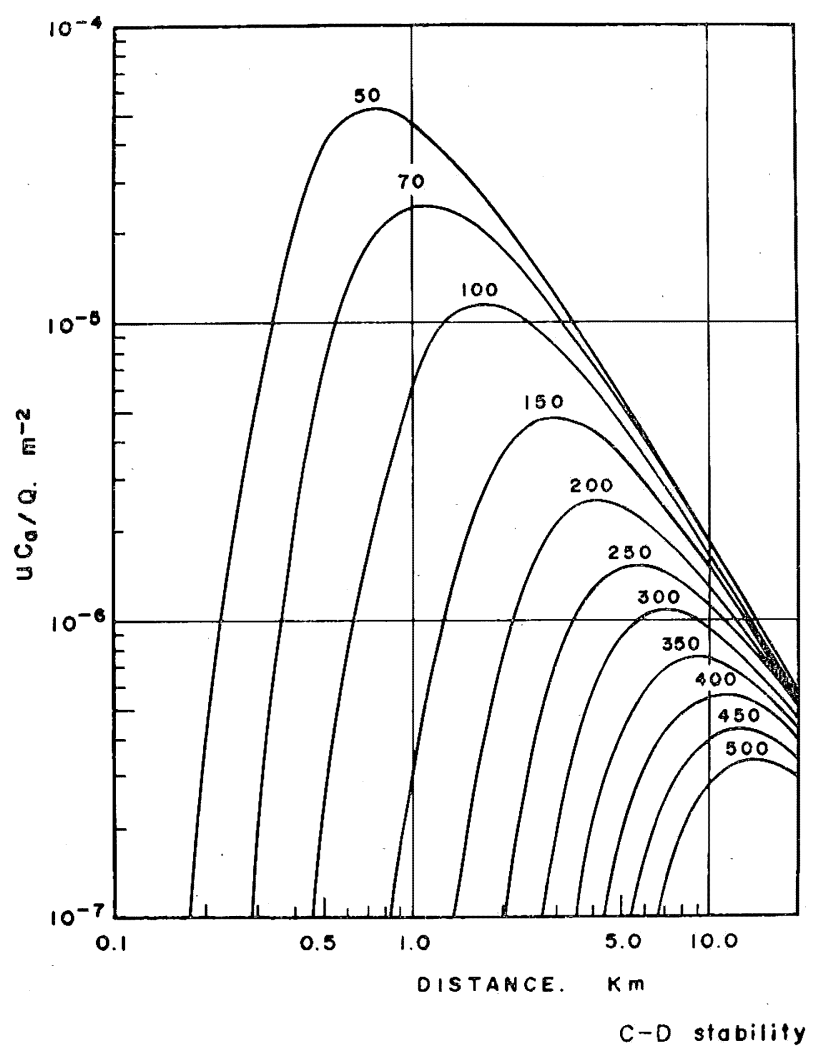

Fig. 18. Normalized surface axial concentration versus downwind distance curves in case of C-D Pasquill stability. Numeral shows the centerline height of concentration in meters.

For reference the surface concentration when only one centerline height is at $200 \mathrm{~m}$ and the Pasquill stability of $\sigma_{z}$ is $C-D$ is given below.

\begin{tabular}{c|ccccc}
\hline$x$ & 1 & 2 & 3 & 4 & $\mathrm{~km}$ \\
\hline$\frac{u C_{a}}{Q}$ & 0 & 0.8 & 2.1 & 2.5 & $\times 10^{-6} \mathrm{~m}^{-2}$ \\
\hline
\end{tabular}

\section{Concluding remarks}

It is usual that there is one centerline height of concentration corresponding to one release height of tracer. However, the diffusion experiment shows that, on some occasions, there apear two centerline heights. It is not necessarily made clear here under what meteorological condition one centerline height is split into two. A tentative conclusion at the present stage is that it is associated with the thermal stratification such that the upper stable layer lies on the lower relatively unstable layer and the tracer is released in the upper stable layer. When the tracer is released in the lower layer, there occurs only one centerline height. 


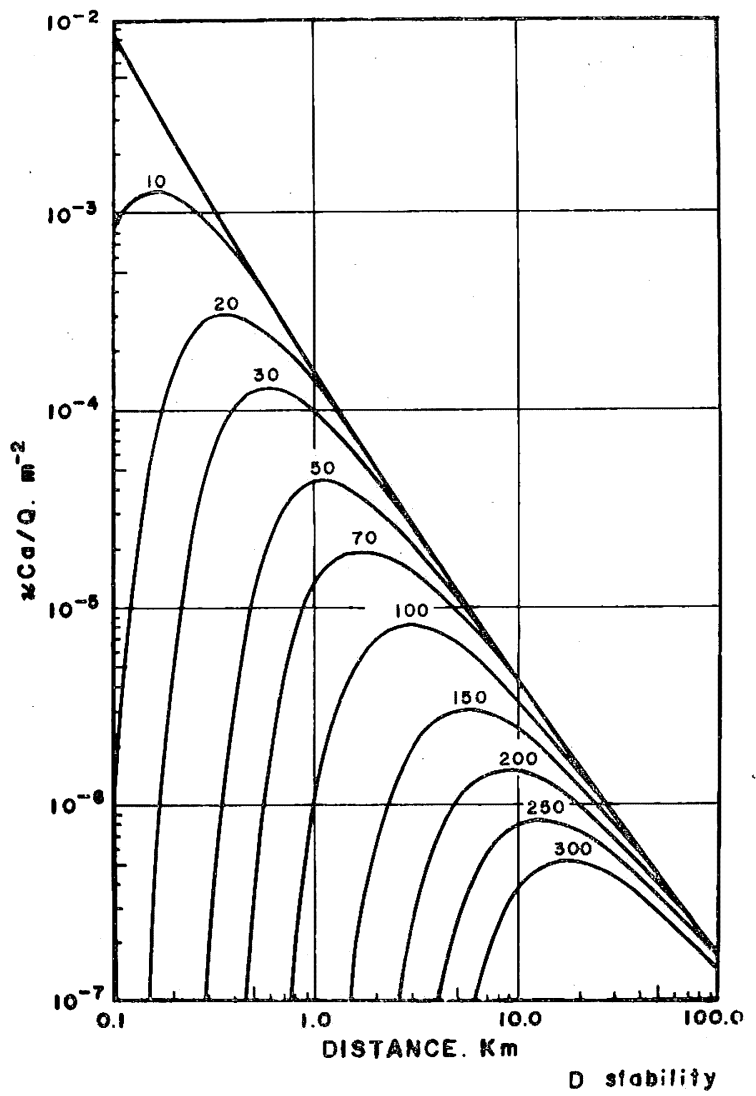

Fig. 19. Same as Fig. 18 but for D Pasquill stability.

Anyway, when the splitting of centerline height occurs, the surface concentration is dominated by the lower-level centerline height and is extraordinarily high near the source in the light of tracer release height. The higher Pasquill stability of $\sigma_{z}$ in the lower layer is also responsible for the high surface concentration.

The present conclusion comes from the diffusion experiment when the tracer release height is $200 \mathrm{~m}$. There is no evidence whatever that, when the effective stack height or tracer release height exceeds $300 \mathrm{~m}$, the same phenomenon occurs.

However, the present result of analysis is serious from the standpoint of practical air pollution control and suggests that, when the effective stack height is $200 \mathrm{~m}$ to $300 \mathrm{~m}$, there may occur an extraordinarily high surface concentration near the source not expected from the effective stack height.

\section{References}

SAKURABA, S., M. Moriguchi and I. YAMAZI, 1972: The elevated-source diffusion at coastal regions. Pap. Met. Geophys., 23, 307-328.

Turner, D.B., 1967 : Workbook of atmospheric dispersion estimates. Public Health Service, USA, p. 9 . 


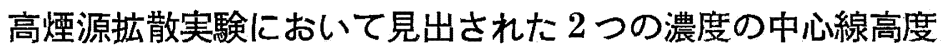

\author{
桜庭信一, 森口 実, 山路 勲
}

濃度の中心線高度を $\bar{z}$, 濃度の鉛直幅を $\sigma_{z}$ とすると，点源に対する濃度の鉛直分布は，ふ心つら一組の $\left(\bar{z}, \sigma_{z}\right)$ で表現できる。このとき濃度の鉛直分布に極大值は一つしかない。すなわち煙源付近では極大值 は $\bar{z}$ の高度に，煙源から遠いところで地表からの反射濃度が卓越してくると極大值は地表に起る。ところ が濃度の鉛淔分布に 2 つ極大值が起る例が，いくつかトレーサーによる拡散実験で見出された。典型的な のが壬生川地域（愛媛県の臨海地域）に拉ける拡散実験結果である。このような濃度分布を表現するには $\left(\bar{z}, \sigma_{z}\right)$ の 2 組の值を要する。すなわら $\bar{z}$ は 2 つり，刘応して異なる $\sigma_{z}$ を持つ。

8 月 8 日の壬生川拡散実験では第一回はトレーサ一散布高度が $200 \mathrm{~m}$ で濃度鉛直分布は $0.9,2.0,3.6 \mathrm{~km}$ の 3 点で測定したが, 解析結果は

$$
\begin{array}{ll}
\bar{z}_{2} \approx 200 \mathrm{~m} & \text { 対応する } \sigma_{z} \text { の Pasquill 安定度 } D \text { または } D-E \\
\bar{z}_{1} \approx 100 \mathrm{~m} & \sigma_{z} \text { の Pasquill 安定度 } C \text { または } C-D
\end{array}
$$

$\bar{z}_{2} \approx 200 \mathrm{~m}$ がトレーサー散布高度に対応可ることは自明だが，それ以外に $\widetilde{z}_{1} \approx 100 \mathrm{~m}$ の高度に新しい中心 線高度が出現したことになる。この結果は極めて重要であって, 地表濃度は煙源付近（少なくとも風下距離 $4 \mathrm{~km}$ 位まで）では $\bar{z} \approx 100 \mathrm{~m}$ 飞中心線高度をるつ濃度によって決まり， $\bar{z}_{2} \approx 200 \mathrm{~m}$ は関係しない。すなわち 地表濃度の立場からは $\bar{z}$ は $200 \mathrm{~m}$ でなく $100 \mathrm{~m}$ であるといらことになる。

約 40 分遅れて第 2 回の実験がなされ，トレーサー散布高度は $100 \mathrm{~m}$ に変更された。この時の鉛直分布は濃 度の極大值が 1 つのふつら型で

$$
\bar{z} \approx 100 \mathrm{~m} \quad \sigma_{z} \text { の Pasquill 安定度 } C \text { または } C-D
$$

濃度の中心線が 2 つ分裂する現象が何によるかは今の段階では必ずしも明瞭ではないが，トレーサー散 布高度が安定なてい減層中にあり，この下に地表付近まで中立層か，これに近い層があるとき，起るのでは ないかと考光ている。このような温度成層は海風が日中，内陸で変質するときふつらに見られる。

ほとんど同じ大気成層内でトレーサー散布高度 $200 \mathrm{~m}$ のとき中心線高度が 2 つ出現し，100mのとき 1 つ というのは注目すべきである。いずれにせよ有効煙突高 $200 \mathrm{~m}$ 程度のとき煙源付近に異常な高濃度の出現の 可能性を示している。有高煙突高が $300 \mathrm{~m}$ 以上のとき同じ現象が起るかどらかはもち論かからない。 